\title{
NANO-BATTERY TECHNOLOGY FOR EV-HEV PANEL: A PIONEERING STUDY
}

\author{
Ataur Rahman, M. RaShid, A.K.M. Mohiuddin AND M.N.A. HaWlader \\ Department of Mechanical Engineering, Faculty of Engineering, \\ International Islamic University Malaysia, \\ Jalan Gombak, 53100, Kuala Lumpur, Malaysia. \\ arat@iium.edu.my; mahbub@iium.edu.my;mohiuddin@iium.edu.my; and \\ mehawlader@iium.edu.my
}

(Received: Nov. 2,2015; Accepted: Nov. 10, 2015; Published on-line: Nov. 30, 2015)

\begin{abstract}
Global trends toward $\mathrm{CO}_{2}$ reduction and resource efficiency have significantly increased the importance of lightweight materials for automobile original equipment manufacturers (OEM). $\mathrm{CO}_{2}$ reduction is a fundamental driver for a more lightweight automobile. The introduction of Electrical Vehicles (EVs) is one initiative towards this end. However EVs are currently facing several weaknesses: limited driving range, battery pack heaviness, lack of safety and thermal control, high cost, and overall limited efficiency. This study presents a panel-style nano-battery technology built into an $\mathrm{EV}$ with $\mathrm{CuO}$ filler solid polymer electrolyte (SPE) sandwiched by carbon fiber (CF) and lithium (Li) plate. In addition to this, an aluminum laminated polypropylene film is used as the electromagnetic compatibility (EMC) shield. The proposed battery body panel of the EV would reduce the car weight by about $20 \%$, with a charge and discharge capacity of $1.5 \mathrm{kWh}$ ( $10 \%$ of car total power requirement), and provide the heat insulation for the car which would save about $10 \%$ power consumption of the air conditioning system. Therefore, the EV would be benefited by $30 \%$ in terms of energy reduction by using the proposed body. Furthermore, the proposed body is considered environmental-friendly since it is recyclable for use in a new product. However, the main limiting factors of the SPE are its thermal behavior and moderate ionic conductivity at low temperatures. The SPE temperature is maintained by controlling the battery panel charging/discharge rate. It is expected that the proposed panel-style nano-battery use in an EV would save up to $6.00 \mathrm{kWh}$ in battery energy, equivalent to 2.81 liters of petrol and prevent $3.081 \mathrm{~kg}$ of $\mathrm{CO}_{2}$ emission for a travel distance of $100 \mathrm{~km}$.
\end{abstract}

ABSTRAK: Trend global ke arah pengurangan $\mathrm{CO}_{2}$ dan kecekapan sumber telah meningkat dengan ketara pentingnya bahan-bahan ringan bagi pengeluar peralatan asal kereta (OEM). Pengurangan $\mathrm{CO}_{2}$ adalah pemacu asas untuk kereta yang lebih ringan. Pengenalan EV adalah satu inisiatif ke arah ini bagaimanapun EV sedang menghadapi beberapa kelemahan: sasar terhad, bateri pek berat, kekurangan keselamatan dan kawalan haba, kos yang tinggi, dan kecekapan keseluruhan yang terhad. Kajian ini membentangkan gaya panel teknologi nano bateri dibina ke dalam EV dengan elektrolit pengisi $\mathrm{CuO}$ polimer pepejal (SPE) diapit oleh fiber karbon (CF) dan plat lithium (Li). Di samping itu, aluminium berlapis filem polipropilena menggunakan sebagai keserasian elektromagnet (EMC) perisai. Dicadangkan panel badan bateri EV akan mengurangkan berat badan kereta dengan kira-kira 20\%, dengan kapasiti caj dan pelepasan $1.5 \mathrm{kWh}$ (10\% daripada kereta jumlah keperluan kuasa), dan menyediakan penebat haba untuk kereta yang akan menjimatkan kira-kira $10 \%$ penggunaan kuasa sistem penghawa dingin. Oleh itu, EV itu akan mendapat manfaat sebanyak 30\% dari segi pengurangan tenaga dengan menggunakan badan yang dicadangkan. Tambahan pula, badan yang dicadangkan dianggap mesra alam kerana ia boleh dikitar semula untuk digunakan dalam 
produk baru. Walau bagaimanapun, faktor utama yang menghadkan SPE adalah tingkah laku haba dan kekonduksian ionik sederhana pada suhu rendah. Suhu SPE dikekalkan dengan mengawal panel bateri kadar caj / pelepasan. Ia dijangka bahawa dicadangkan gaya panel penggunaan nano bateri dalam kereta EV akan menjimatkan sehingga 6.00 $\mathrm{kWh}$ tenaga bateri, bersamaan dengan 2.81 liter petrol dan mencegah 3,081 $\mathrm{kg}$ pelepasan $\mathrm{CO}_{2}$ untuk jarak perjalanan $100 \mathrm{~km}$.

KEYWORDS: epoxy resin; carbon fiber; lithium thin plate; energy generation; solid electrolyte battery

\section{INTRODUCTION}

The cost of fuel consumption and emission of automobiles have always been a problem for users and the environment. The use of lightweight materials is significantly growing in the automotive industry due to its vehicle traction power reduction and improvement of greenhouse gas (GHG) emission. Lightweight materials offer weight reduction potential at a higher cost - carbon fiber $(\mathrm{CF})$ has the highest weight reduction potential which is $50-60 \%$ lighter than steel as shown in Table 1 . The industrialization of CF may yield a cost decrease up to $70 \%$, thereby making it a significantly more attractive alternative. For example, the average emissions of all models sold by an OEM in one year needs to drop $\mathrm{CO}_{2}$ per $\mathrm{kg}$ from $140 \mathrm{~g}$ in 2012 to $75 \mathrm{~g}$ in 2025 and beyond [1]. The energy source of electric vehicle (EV) is bulky due to the weight of battery pack. This paper presents an innovative potential solution to the problem by developing a new EV body, which is able to reduce the weight of the vehicle and act as a storage of energy, thereby decreasing $\mathrm{CO}_{2}$ emission [2]. The EV body consists of $\mathrm{CF}$ that acts as an anode, $\mathrm{CuO}$ filler ER as the solid electrolyte, and a lithium thin plate as the cathode. Researchers [3] have demonstrated the load bearing capacity and electrochemical characteristics of a structural battery built with carbon nano-fiber-reinforced active material composites. The CF electrochemical characteristics have been studied [4-8] and literature reports that electrochemical potential of $\mathrm{CF}$ against $\mathrm{Li}$ is less than $0.5 \mathrm{~V}$ throughout the state-of-charge (SOC). Specific charge capacity is found to be $372 \mathrm{~mA} \mathrm{~h} / \mathrm{g}$, which is larger than common cathode materials such as $\mathrm{LiCoO}_{2}, \mathrm{LiMn}_{2} \mathrm{O}_{4}$, and $\mathrm{LiFePO}_{4}$ [9-11].

Table 1: Weight reduction potential [1].

\begin{tabular}{llc}
\hline Lightweight Material & Material Replaced & Mass Reduction (\%) \\
\hline Magnesium & steel, cast iron & $60-75$ \\
Carbon fiber composites & steel & $50-60$ \\
Aluminum matrix composites & steel, cast iron & $40-60$ \\
Aluminum & steel, cast iron & $40-60$ \\
Titanium & steel & $40-55$ \\
Glass fiber composites & steel & $25-35$ \\
Advanced high strength steel & mild steel & $15-25$ \\
High steel strength & mild steel & $10-15$ \\
\hline
\end{tabular}

Epoxy resin (ER) is a polymer widely used in a variety of applications such as structural composites, electronics, adhesives and coatings. The cured resins have many useful properties, such as excellent combination of stiffness, strength, chemical resistance, 
insulating properties, electric mobility with filler materials, and environmental stability. However, such epoxy resins tend to be rather inherently brittle in nature with poor crack resistance. Numerous attempts have been carried out to improve its performance, especially in terms of the thermal conductivity of ER [12-15]. A very high micro-filler loading, normally $60 \mathrm{vol} \%$ or even higher, is needed to satisfy percolation thresholds and to obtain a high thermal conductivity to form continuous heat conducting chains. However, conductive metal fillers $\left(\mathrm{Al}_{2} \mathrm{O}_{3}, \mathrm{CuO}\right.$, Graphite) and ER can give a better conductivity due to their higher electrical characteristics and chemical stability [3].The author [3] also reported that by adding $15 \mathrm{wt} \%$ of $\mathrm{CuO}$ filler and $20 \mathrm{wt} \%$ plasticizer at ambient temperature can increase the dielectric properties of solid polymer electrolyte. A hybrid filler comprised of carbon nano materials has been studied [16] and reported that a remarkable thermal conductivity of $5 \mathrm{~W} / \mathrm{mK}$ can be achieved with an extremely high concentration of nano fillers of $\mathrm{CuO}$ of about $50 \mathrm{wt} . \%$.

\section{MATERIALS AND METHODS}

\subsection{Mathematical Modeling}

The description of the mathematical models for the estimation of anode, and electrolyte electric and thermal conductivity, panel-style battery structure, development of $\mathrm{CF}$ specimens and $\mathrm{CuO}$ filler solid polymer electrolyte (SPF) is the core discussion of this section. The electrical conductivity is the major concern of this paper's discussion. Different wt\% of filler materials are synthesized with epoxy resin (ER) to enhance its electron mobility or ionic conductivity and thermal conductivity. The electrical conductivity of SPE can be estimated by using the equation:

$$
\sigma_{c}=\frac{4}{\pi}\left(\frac{d_{c}}{d^{2}} \cos ^{2} \theta\right)\left(v_{p} \sigma_{f}\right)(\gamma)(x)
$$

where, $\sigma_{c}$ is the conductivity of the composite, $\sigma_{\mathrm{f}}$ is the conductivity of the fibers, $d_{c}$ the diameter of the circle contact, $\mathrm{d}$ is the diameter of the fiber, $l$ is the average fiber length, $\mathrm{x}$ represents a factor depending on the contact number of fibers, and $\theta$ is the fiber orientation angle.

The dielectric strength of the $\mathrm{CuO}$ filler ER electrolyte indicates the potentiality of the SPE for charge storage and release. The breakdown voltage (considered as cut off voltage, $\mathrm{V}_{\text {cut-off }}(\mathrm{kV})$ of the SPE and the dielectric strength, $\mathrm{E}(\mathrm{kV} / \mathrm{mm})$ can be calculated as, $\mathrm{E}=$ $\mathrm{V}_{\text {cut-off }} / \mathrm{t}$, where, $\mathrm{t}$ is the thickness of the sample in millimeters. Although the $\mathrm{V}_{\text {cutt-off }}$ is not expected from the SPE as it will be in continuous charging and discharging mode by the vehicle regenerative braking system (RGB) power. The voltage of the proposed EV body (nano-battery) can be estimated by considering it as a capacitor:

$$
V_{d}=\frac{\Delta C}{2(2 C+\Delta C)}\left(V_{c}\right)
$$

where, $\mathrm{V}_{\mathrm{d}}$ is the developed voltage from EV body in volts, $\mathrm{V}_{\mathrm{c}}$ is the charging voltage of the $\mathrm{CuO}$ filler $\mathrm{ER}$ in volts, and $\mathrm{C}$ is capacitance in farads. $\mathrm{V}_{\mathrm{d}}$ will be zero if the solid polymer electrolyte state-of-discharge (SoD) reaches $85 \%$ of the state-of-charge (SoC). The capacitance of the proposed body can be estimated as,

$$
\operatorname{SoC} \operatorname{Cof}=\varepsilon_{c} \frac{A}{d}
$$


with $\varepsilon_{c}=\varepsilon_{m}+\frac{2 \cdot \phi \cdot \varepsilon_{m} \cdot \varepsilon_{f}}{2 \varepsilon_{m}+(1-\phi) \cdot \varepsilon_{f}}$

where, $\varepsilon_{\mathrm{c}}, \varepsilon_{\mathrm{f}}$, and $\varepsilon_{\mathrm{m}}$ is the dielectric constant of composite $(\mathrm{CF})$, filler $(\mathrm{CuO})$ and matrix (ER), $\mathrm{A}$ is area of plates in $\mathrm{m}^{2}$, and $\mathrm{d}$ is the distance between plate in $\mathrm{m}$.

Instantaneous charging current $\left(\mathrm{I}_{\mathrm{c}}\right)$ of battery can be estimated as,

$$
I_{c}=\frac{\operatorname{SoD}(\tau) \text { of } C}{\tau_{s}}\left(V_{d(\tau)}\right)
$$

where, $I_{s}$ is the instantaneous charging current of the capacitor in ampere, $C_{s}$ is the instantaneous capacitance, $\mathrm{V}_{\mathrm{d}(\mathrm{s})}$ is the instantaneous discharge voltage developed by the car body in time $t_{s}$. $I_{s}$ will be more if the there is no gap between the (i) $\mathrm{CuO}$ filler polymer electrolyte and the carbon fiber (anode electrode), and the (ii) $\mathrm{CuO}$ filler polymer electrolyte and the lithium thin plate (cathode electrode). In this case, there will be an increase in the movement of electrons and the current flow. Electric conductivity of $\mathrm{CuO}$ filler ER has been measured after sandwiching with $\mathrm{CF}$ and Li-plate. The discharge current of the body is kept in the range of 20-35 A to avoid the heating effect, which might melt the ER film. Total heat generated $\left(\mathrm{Q}_{\text {gen }}\right)$ inside a battery due to the electron mobility $q_{\text {joule }}$ can be expressed by using the equation [17]:

$$
\begin{gathered}
\dot{Q}_{\text {gen }}=\left(\frac{T_{m} \Delta S_{i}}{n F}(i)+i^{2} R+Q \text { solar }\right) \\
\text { with } \Delta S=\int_{T_{i}}^{T_{b a t}} \frac{C_{p}}{T} d T=C_{P} \operatorname{Ln} \frac{T_{b a t}}{T_{i}}
\end{gathered}
$$

The proposed body would be able to reduce the car weight by about $20 \%$, charge and discharge capacity of $1.5 \mathrm{kWh}$ (10\% of car total power requirement), and provide the heat insulation for the car which would be able to save about $10 \%$ power consumption of the air conditioning system. Therefore, the EV would be benefited by $30 \%$ in terms of energy by using the proposed body. The insulating heat of the proposed body can be estimated based on the equation:

$$
Q=\int_{0}^{t}\left[k_{1} \frac{\partial A_{1}}{\partial x_{1}}\left(T_{\alpha}-T_{1}\right)+k_{2} \frac{\partial A_{2}}{\partial x_{2}}\left(T_{1}-T_{2}\right)+k_{3} \frac{\partial A_{3}}{\partial x_{3}}\left(T_{2}-T_{i c}\right)\right] d t
$$

where, $\mathrm{k}_{1}, \mathrm{k}_{2}$, and $\mathrm{k}_{3}$ are the coefficient of heat conductivity of CF, electrolyte and Li-plate respectively, $\mathrm{x}_{1}, \mathrm{x}_{2}, \mathrm{x}_{3}$ are the thickness of $\mathrm{CF}$, electrolyte and Li-plate respectively, $\mathrm{A}_{1}$, $A_{2}$, and $A_{3}$ are the area of $C F$, electrolyte and Li-plate respectively, $T_{\alpha}$ is the environmental temperature, $\mathrm{T}_{1}$ is the temperature of $\mathrm{CF}, \mathrm{T}_{2}$ is the temperature of solid electrolyte and $\mathrm{T}_{\mathrm{ic}}$ is the temperature inside the cabin ${ }^{\circ} \mathrm{C}$. At EV starting time, the inside cabin temperature is always in the range of $18-20^{\circ} \mathrm{C}$.

\subsection{Development of Panel Type Nano-battery}

The structural battery has been developed by using $\mathrm{CF}$ as the anode, $\mathrm{CuO}$ filler ER as the electrolyte and lithium thin plate as the cathode, as shown in Fig. 1. The carbon fiber (CF) plate was developed using Araldite CY231 epoxy resin with an anhydride hardener Aradur HY925. A mold was used, built with two copper alloy plates, with a spacer distance of $200 \mu \mathrm{m}$. The nano-particle $\mathrm{CuO}$ filler ER solidified electrolyte specimens was 
fabricated by mixing of $0.1 \mathrm{wt} \%, 0.3 \mathrm{wt} \%, 0.5 \mathrm{wt} \%, 1 \mathrm{wt} \%, 3 \mathrm{wt} \%$ and $5 \mathrm{wt} \%$ of $\mathrm{CuO}$ with liquid ER. The mixtures were casted into the mold and post cured for 24 hours at $140^{\circ} \mathrm{C}$.

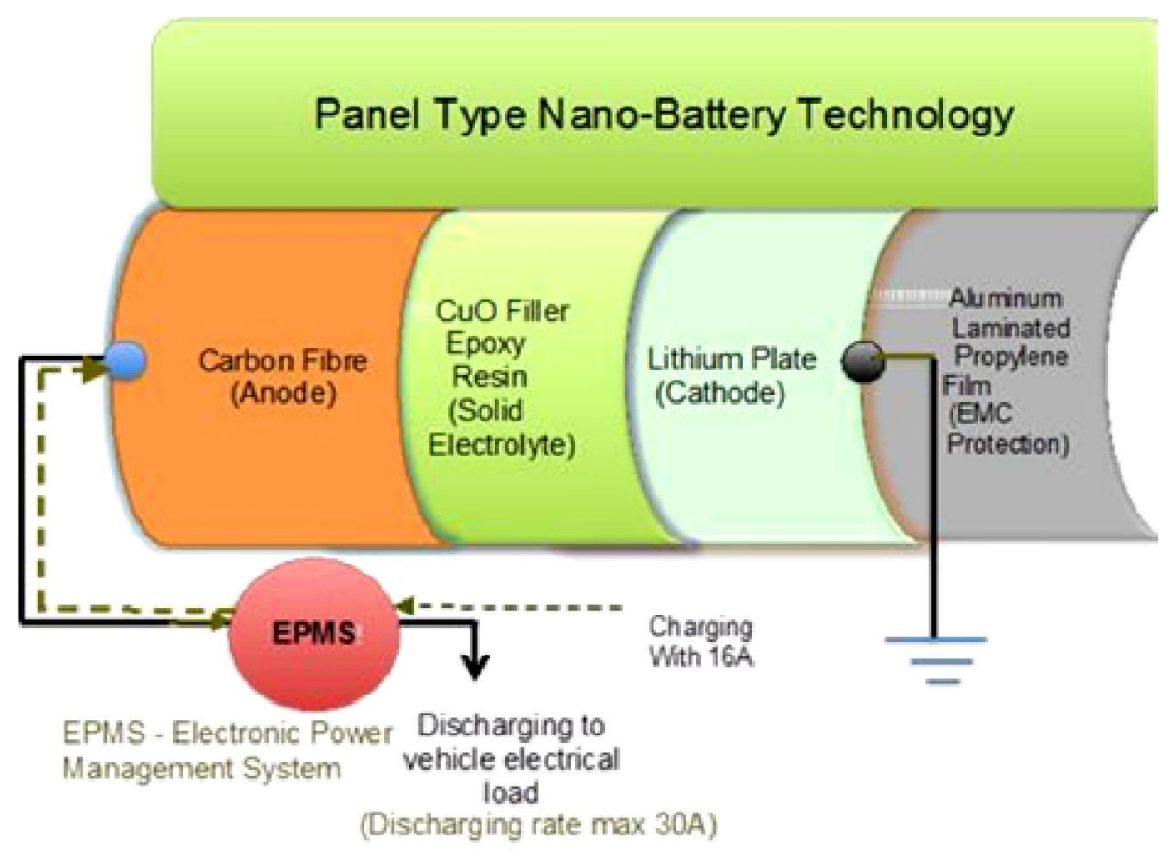

Fig. 1: Panel type nano-battery technology.

Aluminium laminated polypropylene film has been used with the proposed body panel to prevent EMC effect on the passenger cabin. The allowable temperature of the body panel was controlled to be in the range of $20-30^{\circ} \mathrm{C}$ both in charging and discharging mode, by using a resistor-capacitor circuit. Figure 1 shows the panel type nano-battery where the charging and discharging rate can be controlled by an electronic power management system [18]. Fabrication of the composite CF plate was achieved using the vacuum bagging method. The hand lay-up technique considered constructing the $\mathrm{CF}$ through integration of resin and reinforcement (fiber) components. Special care was taken to fabricate the CF to avoid the surface pockets, uneven surface, and pinholes. A few specimens of carbon fiber with different thicknesses and plies have been fabricated for the strength and conductivity testing. Four layers of carbon fiber sheet with $10.0 \mathrm{~cm}$ length and $10.0 \mathrm{~cm}$ height has been fabricated. The epoxy resin and the hardener were mixed together with a ratio of $2: 1$. The presence of air was detected if the maximum level of vacuum could not be achieved $\left(-28^{\prime \prime} \mathrm{Hg}\right)$. A description of the sample is presented in Table 2. The solid polymer electrolyte (SPE) was made with a casting technique by using acetonitrile, polyethylene oxide (PEO), copper oxide $(\mathrm{CuO})$ and ethylene carbonate. The polyethylene oxide acts as a host matrix, acetonitrile as a dissolver, copper oxide as the filler and ethylene carbonate as the plasticizer. The polyethylene oxide was dissolved into acetonitrile. The $\mathrm{CuO}$ was mixed with polyethylene to toughen the surface and enhance the ionic conductivity of SPE. The SPE nano- scale specimens was made with : (i) $\mathrm{CuO}$ filler of $15 \%$ wt and ethylene carbonate of $20 \%$ wt, (ii) $\mathrm{CuO}$ filler of $10 \%$ wt and ethylene carbonate of $30 \% \mathrm{wt}$, (iii) $\mathrm{CuO}$ filler of $5 \% \mathrm{wt}$ and ethylene carbonate of $35 \%$ wt. The mixture of $\mathrm{CuO}$ and ethylene carbonate was stirred for 24 hours to arrive at a homogeneous solution at room temperature and was stored in a dry place. 
Table 2: Description of the specimens.

\begin{tabular}{lcccccc}
\hline & $\begin{array}{c}\mathbf{1}^{\text {st }} \\
\text { Specimen }\end{array}$ & $\begin{array}{c}\mathbf{2}^{\text {nd }} \\
\text { specimen }\end{array}$ & $\begin{array}{c}\mathbf{3}^{\text {rd }} \\
\text { specimen }\end{array}$ & $\begin{array}{c}\mathbf{4}^{\text {th }} \\
\text { specimen }\end{array}$ & $\begin{array}{c}\mathbf{5}^{\text {th }} \\
\text { specimen }\end{array}$ & $\begin{array}{c}\mathbf{6}^{\text {th }} \\
\text { specimen }\end{array}$ \\
\hline Number of plies: & 3 layers & 3 layers & 3 layers & 6 layers & 3 layers & 3 layers \\
Size: & $200 \mathrm{~mm}$ & $200 \mathrm{~mm}$ & $200 \mathrm{~mm}$ & $200 \mathrm{~mm}$ & $200 \mathrm{~mm}$ & $200 \mathrm{~mm}$ \\
Nominal thickness: & $1.17 \mathrm{~mm}$ & $1.24 \mathrm{~mm}$ & $1.18 \mathrm{~mm}$ & $2.29 \mathrm{~mm}$ & $2.35 \mathrm{~mm}$ & $2.39 \mathrm{~mm}$ \\
Mass: & $12.85 \mathrm{~g}$ & $13.59 \mathrm{~g}$ & $12.5 \mathrm{~g}$ & $24.51 \mathrm{~g}$ & $26.72 \mathrm{~g}$ & $26.9 \mathrm{~g}$ \\
\hline
\end{tabular}

\section{RESULTS}

Experimental studies of the composite panel structure of $\mathrm{EV}$ built with a $\mathrm{CuO}$ filler ER sandwiched by CF and Li plate has carried out for the: (i) tensile and impact testing of $\mathrm{CF}$, (ii) microscopic testing of $\mathrm{CuO}$ filler $\mathrm{ER}$, (iii) thermal and electric conductivity of SPE, (iv) ionization characteristics of Li thin plate and (v) electric charge storing and releasing capacity of composites structural panel.

Table 3: Strength of carbon fiber.

\begin{tabular}{ccccc}
\hline $\begin{array}{c}\text { Number of } \\
\text { woven plies }\end{array}$ & $\begin{array}{c}\text { Specimen } \\
\text { no. }\end{array}$ & $\begin{array}{c}\text { Nominal } \\
\text { thickness } \\
(\mathbf{m m})\end{array}$ & $\begin{array}{c}\text { Maximum } \\
\text { force (N) }\end{array}$ & $\begin{array}{c}\text { Maximum } \\
\text { stress } \\
\left(\mathbf{N} / \mathbf{m m}^{2}\right)\end{array}$ \\
\hline \multirow{3}{*}{3} & 1 & 1.17 & 3789.6 & 101.06 \\
& 2 & 1.24 & 5271.3 & 140.57 \\
& 3 & 1.18 & 5801.1 & 114.69 \\
\cline { 2 - 5 } 6 & 4 & 2.29 & 17369.2 & 458.7 \\
& 5 & 2.35 & 17445.0 & 465.2 \\
& 6 & 2.39 & 17507.2 & 466.86 \\
\hline \multirow{2}{*}{9} & 7 & 2.90 & 29928.8 & 798.1 \\
& 8 & 2.85 & 27988.1 & 787.29 \\
& 9 & 2.81 & 29969.9 & 780.20 \\
\hline
\end{tabular}

\subsection{Tensile and Impact Testing}

The CF tensile strength test was carried out based on ASTM D30392 with nine specimens by using a Universal Testing Machine MTS model 744, with a hydraulic grip and MTS 632 12C-20 extensometer at a constant speed of $2.0 \mathrm{~mm} / \mathrm{min}$ at room temperature. Table 3 shows the strength of the carbon fiber $(\mathrm{CF})$. The maximum force indicated in the table is the allowable force for the specimen. If the force increases more than the allowable force, the specimen fails. Figures 2 and 3 show the supporting force by the specimen before failure. The maximum force and elongation (Fig. 2) before failure are $5.8 \times 10^{3} \mathrm{~N}$ and $3 \mathrm{~mm}, 16.25 \times 10^{3} \mathrm{~N}$ at elongation of $3.9 \mathrm{~mm}, 29.5 \times 10^{3} \mathrm{~N}$ at $4.9 \mathrm{~mm}$ for the woven number of plies 3, 6, and 9 respectively. While, the maximum stress (Fig. 4) at the failure mode is recorded as $114.69 \mathrm{kN} / \mathrm{m}^{2}, 458.7 \mathrm{kN} / \mathrm{m}^{2}$ and $780.2 \mathrm{kN} / \mathrm{m}^{2}$ respectively. 


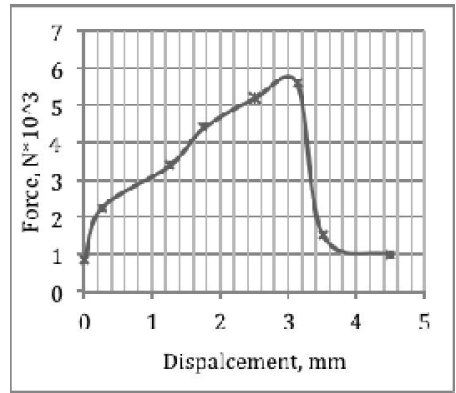

(a)

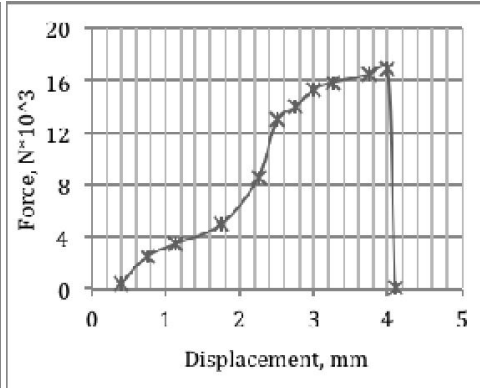

(b)

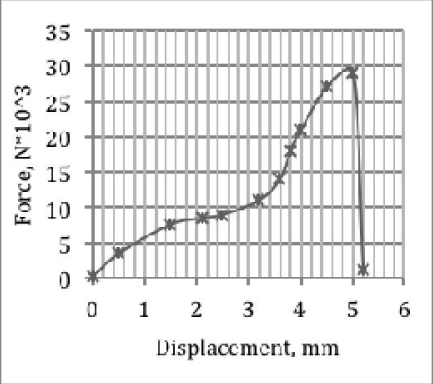

(c)

Fig. 2: Tensile test for force vs displacement, (a) Specimen \#1 (woven plies 3), (b) Specimen \#4 (woven plies 6), (c) Specimen \# 7 (woven plies 9).

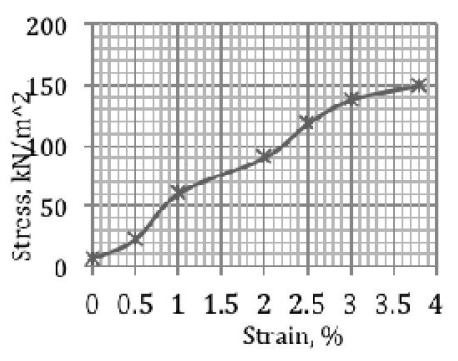

(a)

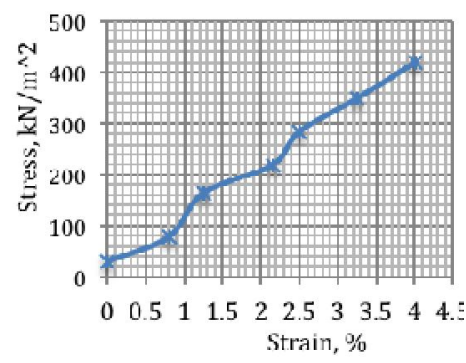

(b)

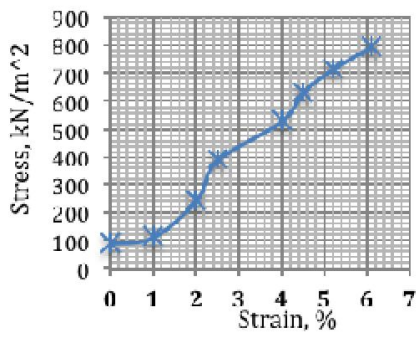

(c)

Fig. 3: Tensile test for stress vs strain, (a) Specimen \#1 (woven plies 3), (b) Specimen \#4 (woven plies 6), (c) Specimen \# 7 (woven plies 9).

Impact testing of the CF for a plate thickness of $2.29 \mathrm{~mm}$ was conducted using an impactor as shown in Fig. 4. Figure 4(a) shows that the plate can absorb a maximum Zforce (load) of $1.22 \mathrm{kN}$ in $2.2 \mathrm{~s}$ and can absorb maximum energy of $5 \mathrm{~J}$ in $8 \mathrm{~s}$. The failure of the plate occurs after $2.2 \mathrm{~s}$ even increasing the load. Figure 4(b) shows that the plate can absorb a maximum of $7.25 \mathrm{~J}$ at $8 \mathrm{~s}$ when the impact energy applied is $10 \mathrm{~J}$. Based on the result it is concluded that the CF plate of thickness $2.29 \mathrm{~mm}$ is not suitable for the car even for the roof.
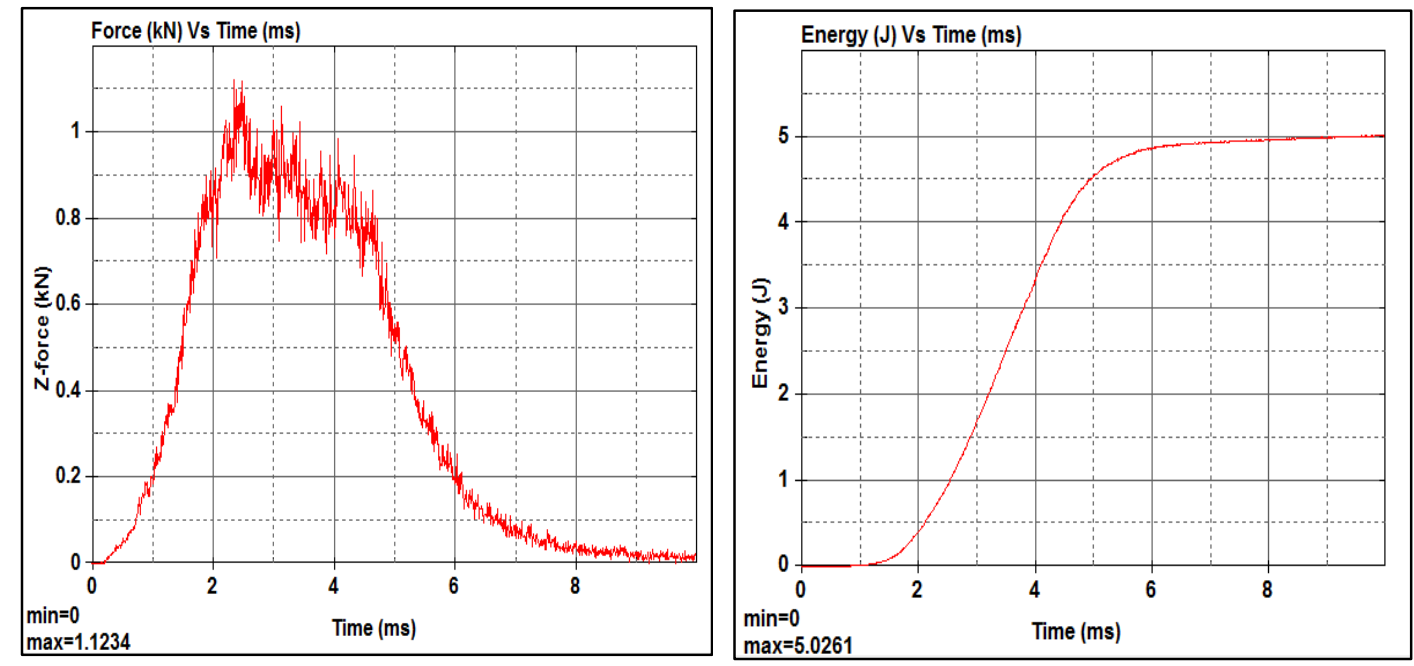

(a) $5 \mathrm{~J}$ 

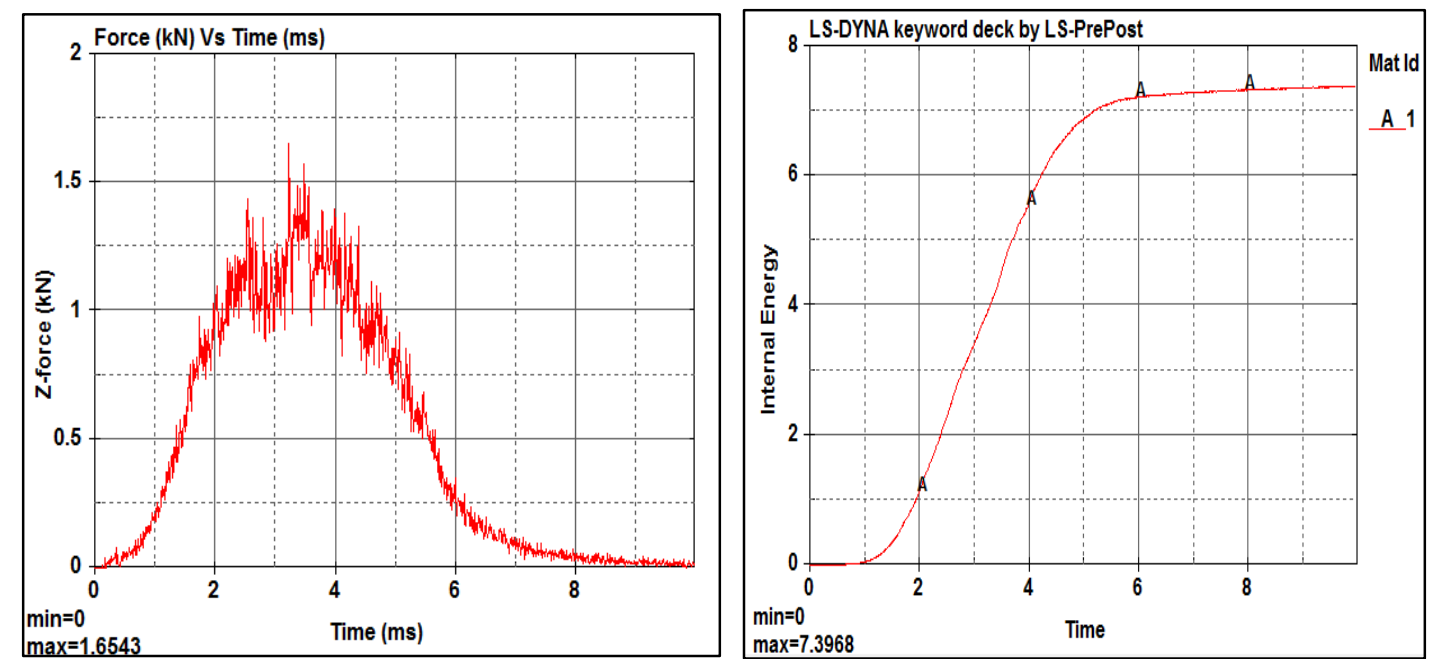

(b) $10 \mathrm{~J}$

Fig. 4: Impact testing of CF for specimen 1 of thickness $2.29 \mathrm{~mm}$ with (a) $5 \mathrm{~J}$, (b) $10 \mathrm{~J}$.

\subsection{Microstructure Test of SPE}

Scanning Electron Microscopic (SEM) analysis was conducted to observe the surface morphology in terms of distribution of copper oxide particles in the matrix, resin copper interface, and thermal and ionic conductivity by using JEOL, JSM 6100. The sample of SPE was coated by JPC-1600 Auto Fine Coating machine with copper to avoid charge build-up, so that the interface of $\mathrm{CuO}$ and ER and deformation behavior could be clearly identified.

The composites were filled with MPS-treated nanoparticles $\mathrm{CuO}$ at a 10 wt.\% loading. The high magnification image in Fig. 5 shows the air gaps between the polymer and the nanoparticle $\mathrm{CuO}$. The agglomerated cluster indicates non-uniform distribution of $\mathrm{CuO}$ within the polymer matrix causing a weak interaction between the $\mathrm{CuO}$ and ER polymeric matrix (i.e., a poor bond in the nanoparticle filled ER-CuO composites). Therefore, the $\mathrm{CuO}$ filler ER has lower tensile strength and smaller electron mobility.

\subsection{Electric Conductivity of SPE}

Solid Polymer Electrolyte (SPE) has many advantages such as high ionic conductivity, high specific energy, solvent-free condition, wide electrochemical stability windows, lightweight and ease of processing. The dielectric properties of fillers and thermal treatment are major determinants for the ionic conductivity enhancement of solid electrolyte. The fillers affect the dipole orientation of the matrix host (i.e, epoxy resin) by their ability to align dipole moments, whereas the thermal history determines the flexibility of the polymer chains for ion migration. The dielectric strength of SPE has been measured after sandwiching by CF and Li foil. A sample of size $200 \times 20 \mathrm{~mm}^{2}$ was placed between the electrodes and the AC voltage at $50 \mathrm{~Hz}$ supply increased. Table 4-6 shows the effectiveness of $\mathrm{CuO}$ electric conductivity, power discharging and charging capacity. 


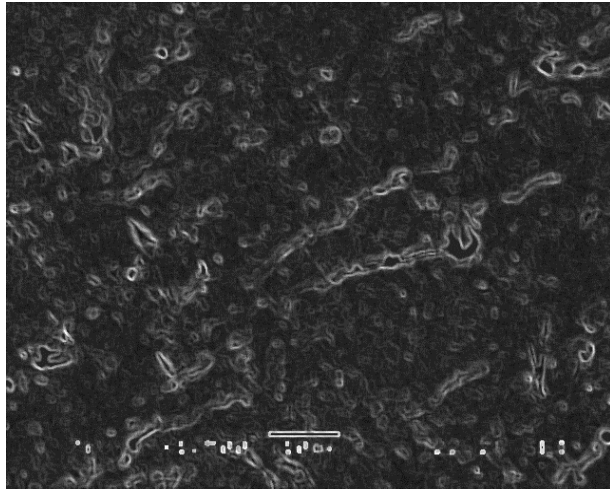

(a)

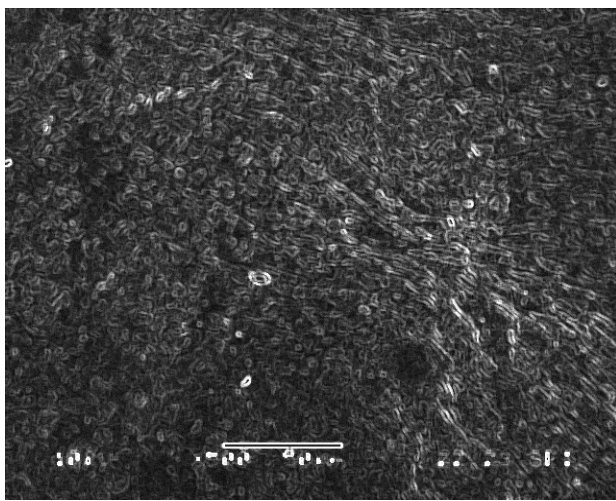

(c)

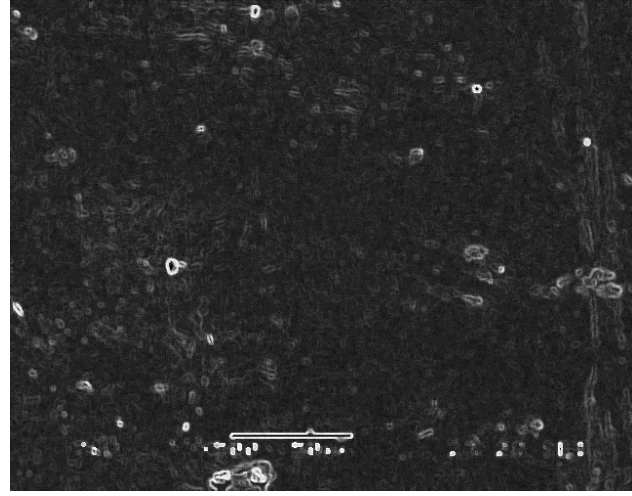

(b)

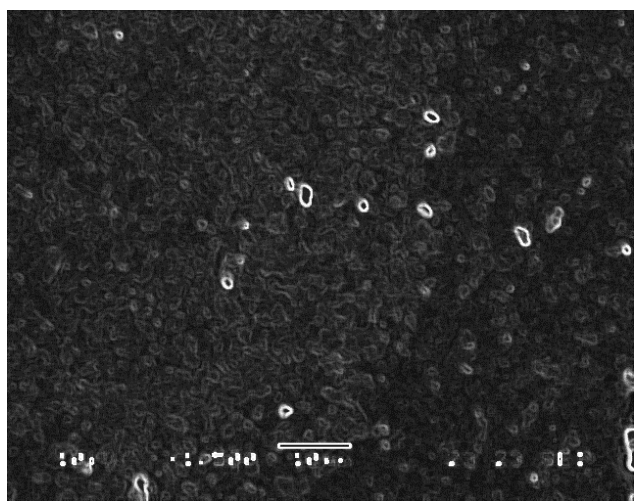

(d)

Fig. 5: SEM micrograph of (a) $5 \mathrm{wt} \%$ (b) $10 \mathrm{wt} \%$ (c) $15 \mathrm{wt} \%$ (d) $20 \mathrm{wt} \%$ of Copper oxide in ER-CuO solution.

Table 4: Electric Conductivity of different wt\% $\mathrm{CuO}$ filler ER.

\begin{tabular}{ccrrrr}
\hline \multirow{2}{*}{$\begin{array}{c}\text { Composition } \\
\text { of CuO } \\
(\% \text { wt })\end{array}$} & $\begin{array}{c}\text { Thickness } \\
\text { of specimen } \\
(\mathbf{m m})\end{array}$ & \multicolumn{4}{c}{$\begin{array}{c}\text { Electric conductivity }\left(\mathbf{1 0}^{\mathbf{3}}\right) \\
\text { Temperature Difference }(\mathbf{\Delta T}),{ }^{\mathbf{0}} \mathbf{C}\end{array}$} \\
\cline { 3 - 6 } & & $\mathbf{3}$ & $\mathbf{6}$ & $\mathbf{9}$ & $\mathbf{1 2}$ \\
\hline 5 & 3.44 & 0.002 & 0.007 & 0.166 & 0.226 \\
10 & 2.86 & 0.008 & 0.011 & 0.207 & 0.226 \\
15 & 3.87 & 0.042 & 0.087 & 0.118 & 0.245 \\
20 & 3.83 & 0.011 & 0.012 & 0.125 & 0.105 \\
\hline
\end{tabular}

Table 5: Power discharging capacity of different $\mathrm{CuO} \%$ wt.

\begin{tabular}{ccccc}
\hline \multirow{2}{*}{$\begin{array}{c}\text { Composition } \\
\text { of CuO } \\
(\% \text { Wt })\end{array}$} & \multicolumn{2}{c}{ Minimum Resistance } & \multicolumn{2}{c}{ Maximum Resistance } \\
\cline { 2 - 5 } & Current (A) & Voltage (V) & Current (A) & Voltage (V) \\
\hline 5 & 0.25 & 1.10 & 2.51 & 2.10 \\
10 & 0.40 & 1.22 & 2.6 & 2.34 \\
15 & 0.66 & 1.26 & 2.9 & 2.45 \\
20 & 0.33 & 1.47 & 3.01 & 2.70 \\
\hline
\end{tabular}

Note: Experimental result has been recorded for the composite specimen size (200mm x 50mm). 
Table 6: Power saving of the car.

\begin{tabular}{|c|c|c|c|c|c|c|}
\hline \multirow{2}{*}{$\begin{array}{c}\text { Compositi } \\
\text { on of CuO } \\
\text { (\% Wt) }\end{array}$} & \multirow{2}{*}{$\begin{array}{c}\text { Vehicle } \\
\text { weight } \\
\text { saving } \\
\text { (kg) }\end{array}$} & \multirow{2}{*}{$\begin{array}{c}\text { Power } \\
\text { saving } \\
(\mathbf{k W})\end{array}$} & \multirow{2}{*}{$\begin{array}{c}\text { Fuel } \\
\text { consumpti } \\
\text { on }(\mathrm{kg} / \mathrm{s})\end{array}$} & \multicolumn{2}{|c|}{$\begin{array}{c}\text { Power produced } \\
(\mathbf{k W})\end{array}$} & \multirow{2}{*}{$\begin{array}{r}\text { Power } \\
\text { saving } \\
\text { (kW) }\end{array}$} \\
\hline & & & & $\mathbf{A}_{\mathbf{P}}\left(\mathbf{m}^{2}\right)$ & $A_{V}\left(m^{2}\right)$ & \\
\hline 5 & 21 & 1.43 & $5.46 \times 10^{-3}$ & 5.28 & 0.792 & 3.55 \\
\hline 10 & 20 & 1.36 & $5.58 \times 10^{-3}$ & 6.08 & 0.912 & 3.18 \\
\hline 15 & 18 & 1.22 & $5.46 \times 10^{-3}$ & 7.105 & 1.065 & 4.03 \\
\hline 20 & 17 & 1.15 & $5.47 \times 10^{-3}$ & 5.78 & 0.867 & 4.36 \\
\hline
\end{tabular}

Figures 6-7 show the power discharge capacity of the panel type nano-battery for different weight percentages (\%wt) of $\mathrm{CuO}$ as the filler of the ER. Figure 6 shows that for $\mathrm{CuO}$ of weight percentage of $15 \%$, the electric conductivity increases almost linearly with increasing temperature. Figure 7(a) shows that $\mathrm{CuO} 15 \%$ wt has higher discharging capacity than others. Figure 7(b) shows that the nano-battery charging voltage (voltage gain) is maximum for a sample with $15 \%$ wt of $\mathrm{CuO}$. Therefore, $\mathrm{CuO}$ as a filler material for the ER can be optimized at $15 \%$ wt filler for the ER in panel style nano-battery. This conclusion agrees with the results in [19].

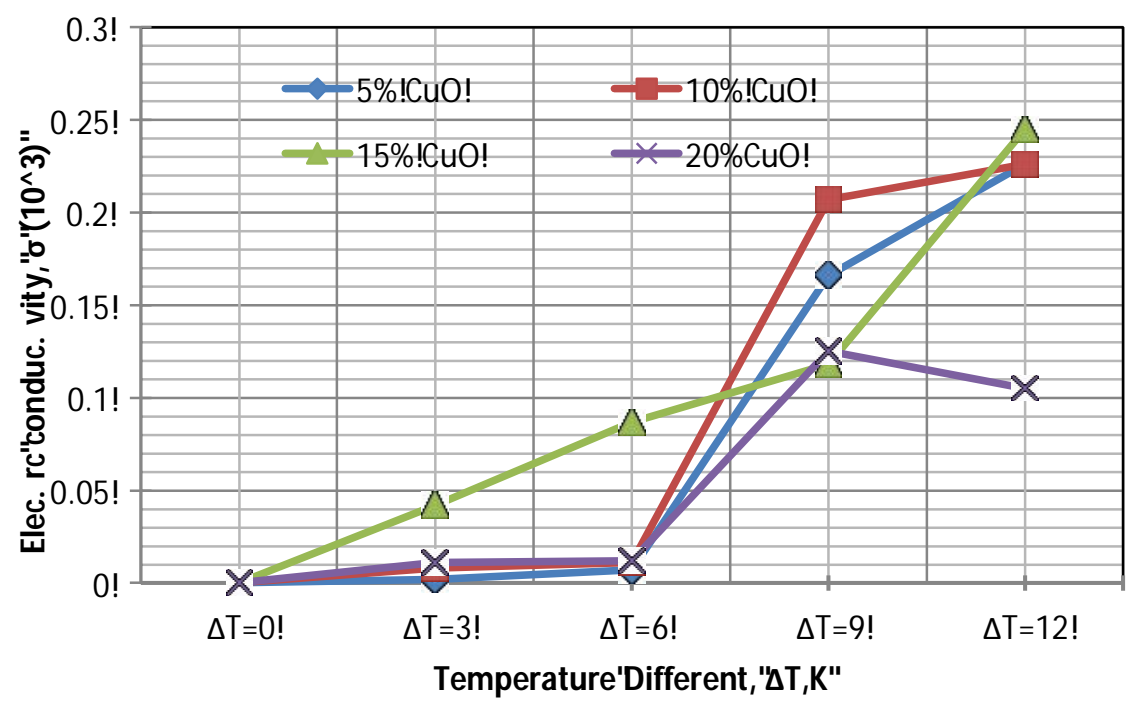

Fig. 6: Electric conductivity vs temperature difference.

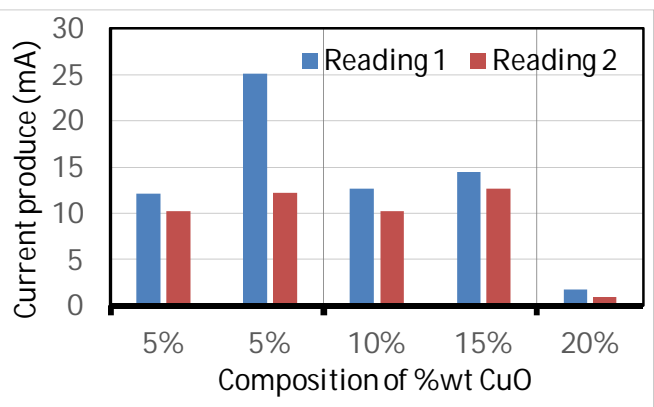

(a) Current produce.

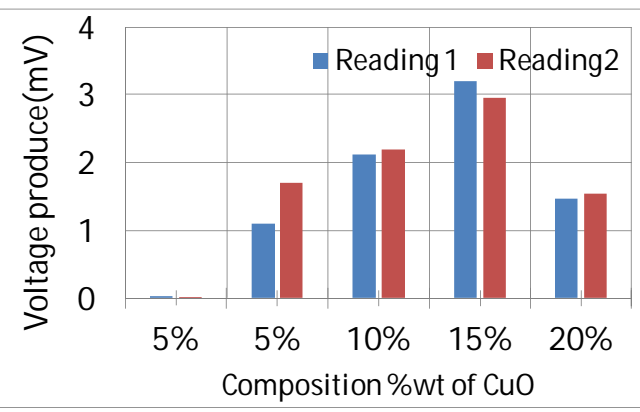

(b) Voltage gain.

Fig. 7: Power discharged and charged by the composite body. 
Table 7: Fuel consumption and emission.

\begin{tabular}{|c|c|c|c|c|c|c|}
\hline \multicolumn{2}{|c|}{ Vehicle weight (kg) } & \multicolumn{2}{|c|}{ Power consumption } & \multicolumn{2}{|c|}{$\begin{array}{c}\mathrm{CO}_{2} \text { reduction per } \\
100 \mathrm{~km} \text { travelling }(\mathrm{g})\end{array}$} & \multirow{2}{*}{$\begin{array}{c}\mathrm{CO}_{2} \text { for th } \\
\text { using of } \\
\text { proposed } \\
\text { composite } \\
\text { body }(\%)\end{array}$} \\
\hline Steel & Composite & Steel & Composite & Steel & Composite & \\
\hline 1033 & 827 & 52 & 36.4 & 87.55 & 70.23 & 19.71 \\
\hline
\end{tabular}

\section{CONCLUSION}

An EV roof built with a composite of $\mathrm{CuO}(15 \% \mathrm{wt})$ filler ER sandwiched by $\mathrm{CF}$ and Li-plate can save power of up to $1.22 \mathrm{~kW}$ due to reduction in weight, and saving cooling power from heat insulating as shown in Table 7. The proposed new battery technology could be considered as a suitable technology for vehicle due to its storing and releasing $3.5 \mathrm{~kW}$ power (energy equivalent to 2.81 liters of petrol) and prevent $6.00 \mathrm{~kg}$ of $\mathrm{CO}_{2}$ emission for every $100 \mathrm{~km}$ distance travelled.

\section{ACKNOWLEDGEMENT}

This study has been conducted to meet one of the objectives of the project "Development of Green Transportation System". The authors are grateful to the Malaysian Ministry of Education (MOE) for financing this project. The authors would like to thank the technicians of International Islamic University Malaysia (IIUM) for helping to conduct this study.

\section{REFERENCES}

[1] Cheah LW. (2010) Cars on a diet: The material and energy impacts of passenger vehicle weight reduction in the U.S. Ph.D. Dissertation, Massachusetts Institute of Technology, Cambridge, MA.

[2] Gacitua W, Ballerini A, Zhang, J. (2005) Polymer nanocomposites: Synthetic and natural fillers a review. MaderasCienc. Y Tecnol., 7:159-178.

[3] Liu P, Sherman E, Jacobsen A. (2009) Design and fabrication of multifunctional structural batteries. J of Power Sources, 189:646-650.

[4] Tanaka, T. (2005) Dielectric nano-composites with insulating properties. IEEE Transactions on Dielectrics and Electrical Insulation, 12(5): 914- 928.

[5] Amaral FA, Dalmolin C, Canobre SC, Nerilso B, Rocha FRC, Biaggio SR. (2007) Electrochemical and physical properties of poly based gel electrolytes for lithium ion batteries. J. power Sources, 164(1):378-7753.

[6] Li Z., Su,G, Wang X, Gao D..(2005) Micro-porous P based polymer electrolyte filled with CuO nanoparticles. Solid State Ionics, 176(23-24):1903-1908.

[7] Manual SA. Nahm KS, Kumar T, Kulandainathan M, Ravi G, Wilson J. (2002) Thermal, electrical and mechanical properties of plasticized polymer electrolytes based on PEO/P blends. Electrochimi Acta, 48(2):205-209.

[8] Thomas JP, Qidwai MA. (2004) Mechanical design and performance of composite multifunctional materials. Acta Materialia, 52:2155-2164.

[9] Hossain S, Kim YK, Saleh Y, Loutfy, R (2006) Overcharge studies of carbon fiber composite-based lithium-ion cells. J Power Sources, 161:640-647.

[10] Flandrois S, Simon B. (1999) Carbon materials for lithium-ion rechargeable batteries. Carbon, 37:165-180. 
[11] Imanishi N, Kashiwagi H, Ichikawa T, et al. (1993) Charge discharge characteristics of meso phase-pitch-based carbon fibers for lithium cells. Journal of the Electrochemical Society 140:315-320

[12] Han Z, Fina A. (2011) Thermal conductivity of carbon nanotubes and their polymer nano composites: A review. Prog. Polym. Sci, 36(7):914-44.

[13] Yang F, Zhao X, Xiao P. (2010) Thermal conductivities of YSZ/Al2O3 composites. J Eur Ceram Soc., 30(15):3111-3116.

[14] Shi Z, Radwan M, Kirihara S, Miyamoto Y, Jin Z. (2009) Enhanced thermal conductivity of polymer composites filled with three-dimensional brush like AlN nano whiskers. Appl Phys Lett, 95,224104.

[15] Cui W, Du F, Zhao J, Zhang W, et al. (2010) Improving thermal conductivity while retaining high electrical resistivity of epoxy composites by incorporating silica-coated multiwalled carbon nanotubes. Carbon, 49(2):495-500.

[16] Li TL, Hsu SLC. (2010) Enhanced thermal conductivity of polyimide films via a hybrid of micro- and nano-sized boron nitride. J Phys Chem B, Vol.114(20): 6825-6833.

[17] Rahman A, Farhan S, Ahmed H, Hawlader, MNA. (2014) Fuzzy controlled evaporative battery cooling system for EVs/HEVs. International Journal of Electric and Hybrid Vehicle System. Inderscience, 8(2):233-240.

[18] Rahman A, Hossain A, Zahirul Alam AHM, Mahbubur R. (2012) Fuzzy knowledge-based model for prediction of traction force of an electric golf car. Journal of Terramechanics, 49(1):13-25.

[19] South JT, Carter RH, Snyder JF, et al. (2005) Multifunctional power-generating and energystoring structural composites for US army applications. Materials Research Society Symposium Proceedings, 851:139-150. 